\title{
Transnational crime of Chinese origin in the EU: False flags and real concerns
}

\author{
Jurij Novak ${ }^{1}$
}

\section{Introduction: attempt to define}

This chapter examines three areas in which we could encounter transnational Chinese criminal activity in the European Union: traditional Chinese organised crime, also known as the Triads; Chinese criminal activity, encompassing sex trafficking and sexual exploitation; and Chinese criminal involvement in the Italian textile industry, which looks into the case of large-scale and rampant Chinese criminality in the city of Prato. While I attempt to de-mystify a number of assumptions about Chinese Triads and Chinese sex trafficking, concerns about criminal practices inside the textile industry are well supported by available evidence and this problem is therefore discussed in the following sections.

Defining 'Chinese' is not as clear as it seems. It can encompass citizens of the People's Republic of China (PRC), Republic of China (ROC, also known as Taiwan) and people of Chinese ethnicity abroad. All these can be perpetrators of crimes, active either in the EU (or in its relevant proximity) or targeting victims in the EU, regardless of the perpetrators' residence. The victims can also be people of Chinese ethnicity, who reside in the EU (legally or illegally), Chinese people abroad. It can also include EU citizens, companies, public services and even state institutions.

The link between the discussed topics lies in Chinese cultural features. It could be argued that a vast area of crimes by Chinese immigrants (e.g. human smuggling and labour trafficking, tax evasion, money laundering,

Jurij Novak, LLB, PhD Candidate, Institute of Criminology at the Faculty of Law, University of Ljubljana. 
etc.) could be characterised as 'culturally specific', i.e. the cultural elements and specific traditions of the crimes in question are significant and should be considered when investigating any such crimes.

\section{False Chinese transnational crime: the 'triad conspiracy' and Chinese sex trafficking}

\section{Chasing the phantom of Chinese Triads}

Studies of organised and transnational crime are often burdened by speculative paradigms which have little, if any, basis in empirical evidence. They also fail to withstand even simple logical analyses. Such speculations often border on pure conjectures, political herd behaviour (Van Duyne and Nelemans, 2011) and even romantic fantasy.

The so-called Chinese Triads are probably the most illustrative example of such unfounded research paradigms (Petta, 2017). Indeed, many Chinese transnational crimes, including but not limited to human smuggling, sex trafficking and illicit drug trafficking, are attributed to Chinese Triads: "an imaginary mystery of a centralised global crime super-organisation" (ibidem). Since even the most avid fans of the triad conspiracy acknowledge that the Triads come only from Hong Kong and Macau, the application of the term "Chinese Triads" beyond these confines is grossly misleading. It would be equally erroneous to label Sicilian, Calabrian, and Neapolitan criminal traditions and OCGs as simply "Italian mafias". It would completely disregard a realistic assumption that each such traditional and related criminal group is quite probably a specific criminal universe of its own.

Nevertheless, the term Chinese Triads often serves as a synonym for all Chinese organised and transnational crime groups. Because there is serious discrepancy between Chinese scholars, sinologists, and historians of China on the one hand and organised crime scholars on the other hand, some short clarification is required.

Secret societies tend to exist in almost every place and era: they may be religious, political or simply criminal or some combination of the three. It should be of no surprise that a country as vast as the Chinese empire had a 
rich history of secret societies (the most legendary one is perhaps the White Lotus society that played an important part in organising a successful popular uprising against the Mongol Yuan dynasty in the $14^{\text {th }}$ century) and clandestine brotherhoods. The latter were usually organised by migrants from the same area for mutual help. The most persistent of these societies were called Societies of Heaven and Earth (Chin. tian di hui), mentioned as early as 1761 (Murray, 1994) as a secret society of migrant workers from Fujian Province. These societies quickly developed a mythology about their founding, shrouded in mystery and obscure legends. They often assumed a political identity, one of secret rebels against Manchu conquerors who established the Qing dynasty. Quite often, they were also involved in criminal activities, mostly smuggling wheat and salt down rivers in defiance of state-imposed monopolies.

British colonial administrators in Shanghai and Hong Kong in the late 19th century who were, following the fashion of those times, often members of masonic lodges, interpreted the tradition of tian di hui through Western knowledge of masonic rituals, demonstrating little understanding for Chinese specifics. Tian di hui societies were viewed simply as an exotic parallel of masonic societies and hence named as 'the Triads' (Petta, 2017). The British colonialists, often paranoid of everything Chinese - going as far as being proudly ignorant of the Chinese language and culture - saw secret societies as a political threat and therefore outlawed all of them, interpreting them as inherently criminal in nature. However, most of the socalled triad societies had no criminal background. It is quite interesting to see these colonial attitudes towards Chinese criminality continuing into modern times.

\section{New appearance}

How should Chinese folklore and history be translated into the world of modern criminal Chinese Triads? It is not uncommon for criminal groups to develop their own mythology or to appropriate an existing one without any historical or even geographical relation to the group itself. The legends touting triad omnipotence exist even today and are believed by criminals, their victims, and by law enforcement alike. Therefore it is rather challenging to prove otherwise. Nevertheless, beliefs are not facts and should not be treated as such. 
So far, the only comprehensive and empirical study of Hong Kong Triads available in English is the monograph The Triads as Business by Yiu Kong Chu (2002) which debunks almost all Western myths about these types of organisations and their criminal capabilities. Chu's research paints a picture of extremely local Organised Crime Groups (OCGs), limited to highly specific criminal activities (e.g. petty extortion of street vendors, tenant harassment aimed at vacating buildings, and night club protection) in Hong Kong and partially Macau. These criminal activities follow the specific environment of Hong Kong and Macau, characterised by high population density, coupled to the economic and cultural necessity of some services, such as illegal cheap labour and sex services. Hong Kong Triads are to some extent incorporated into the informal management of a large port city and show some similarities to the modus operandi of the Camorra clans in Naples or the organised crime families of the 'Ndrangheta (Sergi, 2015).

Hong Kong and Naples have a similar geographic configuration, i.e. both are port cities constructed on sloping terrain. This naturally leads to limited space in the city centres, while the suburbs (Secondigliano and Scampia in Naples, New Territories in Hong Kong) are far away, making them harder to govern. The Camorra gangs and the Hong Kong Triads are both involved in the profitable construction and real estate sector in various ways (persuading tenants to vacate premises marked for development, criminal activity related to public tenders, and supplying illegal workers), in smuggling and counterfeiting, in managing open-air illicit drug markets and in exploiting illegal immigrants (Chu, 2002; Behan, 2005; Saviano, 2006). However, according to official crime statistics, Hong Kong is one of the safest cities in the world (Broadhurst et al., 2007; Hong Kong Monthly Digest of Statistics, 2016). Therefore we can conclude that the Triads exert much less influence on the local population and tend to be much less violent than the Camorra. ${ }^{2}$ Also, since Hong Kong's political

2 According to the Hong Kong Monthly Digest of Statistics (2016), there were only 22 homicides in Hong Kong with a population of more than 7 million people. In Naples City, which has slightly less than a million people, there were 77 homicides (of which 38 were related to the Camorra) in 2016, a stark improvement when compared with the past (Beneduce, 2017). According to the only analysis of triad-related murders in Hong Kong (Lee at al., 2007) there were 124 such murders between 1989 and 1998. For comparison, there were 
system remains firmly in the grip of Beijing, the political influence of the Triads, if any, is probably negligible. The absence of a political dimension to the Triads' activities is in stark contrast to the Camorra and even more so to the 'Ndrangheta (see Sergi, 2015). ${ }^{3}$

According to Chu, Hong Kong Triads lack the ability, knowledge, and resources to become even a 'mid-size player' in transnational criminal activities such as: large-scale smuggling of illicit drugs (heroin and methamphetamine from the Golden Triangle), human smuggling, cyber-crime, etc. Triad members also lack language skills (often not being able to speak even Mandarin Chinese), criminal skills (they are adept at street level crime but not capable of complex tax evasion and money laundering), and international connections to be successful outside of Hong Kong. Furthermore, there is no rational reason for them to leave Hong Kong to which they have adapted quite well. Of course, some triad members do sometimes smuggle drugs or people; however, there is no evidence to suggest that these activities are done on behalf of a larger organisation. Membership of a triad group does not prohibit members from engaging in (usually small scale) criminal projects of their own.

As far as the EU is concerned, there is supposedly a minor triad presence in the UK, limited mostly to petty extortion of Chinese shopkeepers (Silverstone, 2011). No affiliation with larger triad groups in Hong Kong has been proven so far, allowing for the possibility that some ordinary Chinese criminals assume a 'pseudo-triad' identity to be more successful, feared, and respected. In the continental EU, no triad presence has been detected. Since immigration from Hong Kong to the continental EU is negligible at best, we can safely assume that there is probably no triad presence of any kind.

311 Camorra-related murders in the province of Campania between the years 1999 and 2003 (Gazzetta del Mezzogiorno, 2005).

3 But the Triads might have found a new political niche in suppressing Hong Kong pro-democracy movements. In 2014, numerous members of the Umbrella movement were beaten by Triad-affiliated thugs-for-hire in the Mongkok area. See Varese and Wong, 2017. 


\section{The exotic allure of Chinese sex trafficking}

This section discusses the alleged sex trafficking of Chinese young women in the EU and attempts to de-mystify some assumptions.

Sex trafficking is a form of human trafficking. Numerous definitions of human trafficking are perhaps best summed up by Spencer (2014) who defines it as "exploiting human beings commercially in ways that involve degrading treatment". According to Article 3, paragraph (a) of the United Nations Protocol to Prevent, Suppress and Punish Trafficking in Persons (Palermo Protocol), exploitation includes "at a minimum, the exploitation of the prostitution of others or other forms of sexual exploitation, forced labour or services, slavery or practices similar to slavery, servitude or the removal of organs".

It is obvious from the formulation of this provision that prostitution and other forms of sexual exploitation, i.e. sex trafficking, are considered the most important manifestations of human trafficking. If a person is involved in the sex business, consent to such activity or lack thereof are legally completely irrelevant, i.e. the Protocol goes so far that it considers a grown person, who is fully informed about going into sex business abroad and fully consents to it, is a victim of human trafficking (Hoyle et al., 2011). ${ }^{4}$

If international law equates sex trafficking with voluntary prostitution of migrant women, it is hardly a surprise that the mass media follows suit. Indeed, sex trafficking has often been presented as one of the most heinous crimes and appalling social problems of the day (see home pages of NGOs Shared Hope International, Polaris, End Slavery Now, and others). A vast body of literature and countless NGOs and government agencies exist and are dedicated to 'eradicating' this problem.

However, there are numerous objections to such widespread representation. Several authors (Weitzer, 2005, 2007; Zhang, 2009; Gozdziak and Bump, 2008; Spencer, 2014) have offered serious criticisms of basic assumptions and typical narratives about sex trafficking and of flawed and unreliable research methods (e.g. the lack of random samples, very small

4 It seems that the legislators predicted that many victims would fake consent out of fear, but the main problem here is that the sex business often has no rigid roles, i.e. a prostitute might also act as a business intermediary (pimp) or even as a cashier. That means that her status as a victim or a victimiser may com80

pletely depend on temporary circumstances. 
sample sizes, etc.). Critics also point to the lack of empirical research on the topic (especially Gozdziak and Bump, 2008). But we would also be remiss not to mention that the debate on human trafficking has become more balanced and nuanced during the last decade and that more attention has been paid to 'non-sex' trafficking (Alvarez and Alessi, 2011; Baker, 2015; Choi-Fitzpatrick, 2016).

Nevertheless, even the most liberal minded people acknowledge that forced prostitution and sexual slavery are a serious crime. However, the official statistics suggest that these also highly uncommon. ${ }^{5}$ Isolated and extreme cases of forced prostitution, so-called 'atrocity tales' and are therefore used to argue against prostitution in every form, including voluntary and consensual sexual services for profit (again Weitzer, 2005, 2007; Zhang, 2009).

The sensationalist focus on examples of Chinese female immigrants, 'brutally enslaved' or by some other means coerced or at least tricked into prostitution (e.g. Sui, 2017), perpetuates racist stereotypes in a similar way as beliefs in triad-controlled Chinatown underworlds. Horror stories about Chinese prostitutes in seedy massage parlours often coincide with similar stories about brutal and sadistic triad-affiliated pimps and brothel owners.

However, as suggested by Chin (2014; Finckenauer and Chin, 2010) in his qualitative empirical research of 149 Chinese immigrant sex workers in South-East Asia, Los Angeles, and New York, the reality of Chinese sex workers overseas might be entirely different.

China has a long and colourful tradition of prostitution, perhaps best immortalised in the classic erotic novel The Plum in the Golden Vase from the late Ming dynasty. As soon as the Communist People's Republic of China instituted market-oriented reforms in the early 1980s, providing the population with some disposable income, thinly disguised brothels began to flourish again. Despite frequent crack-downs by police in mainland China, prostitution has remained a staple-element of Chinese nightlife and

5 E.g. According to Eurostat report 'Trafficking in human beings' from 2013, 23.600 people were victims of human trafficking in the previous 3 years of which $62 \%$ were trafficked for sexual purposes. This calculation yields 14.632 victims of sex trafficking in 3 years or 4.877 victims a year on average. However, by way of comparison, according to Eurostat, there were 5.211 murders in 2012. Using official data, we can only conclude that murder is a slightly more common crime in the EU than sex trafficking. Moral panic cannot be justified by referencing official statistics. See Chappell, 2013. 
traditional entertainment (Zheng, 2009). The number of prostitutes in the People's Republic of China is estimated to be in the range of 3 to 10 million women (Ebenstein and Sharygin, 2011).

Some of them also accept the risk and voluntarily become sex workers abroad so they can earn higher wages. Because of language barriers, Chinese brothels abroad are mostly frequented by Chinese immigrants, Chinese businessmen, and Chinese tourists. The relative isolation of Chinese prostitutes from the local population - typical for all low-skill blue collar Chinese immigrants, such as cooks, waiters, and vendors - serves only to fortify racist prejudices about Chinese patriarchal violence toward women. But according to Chin, almost all of the interviewed prostitutes knew themselves exactly what kind of work they were getting into abroad and were not tricked or coerced in any way. Some of them emigrated to work as masseuses but even they did not exclude sex work as a source of additional income. Contrary to the prevailing victim stereotype, the prostitutes in Chin's research (2014) often emerge as independent and strong-willed women with considerable business acumen. Extrapolating from research findings, which state that Chinese prostitutes were neither exploited nor mistreated in South-East Asian developing countries with notoriously corrupt or inept law enforcement or in the US, it is safe to assume they are normally not exploited or mistreated in the EU either except for serious cases of abuse which are made much of in the media.

Researching sex businesses (regardless of whether we focus on sex trafficking or other forms) should abstain from 'one-size-fits-all' assumptions and be more attentive to cultural nuances. As it will be demonstrated in the following section, immigrants usually do not adopt the business models of receiving countries, but rather transplant their own. There is no reason to believe that the same assumption does not apply to sex business. Chinese prostitution abroad is different from, say, the notoriously brutal treatment of Albanian prostitutes. According to Arsovska (2015), this often begins with kidnappings, selling daughters into forced marriages, rape, etc. in the Albanian countryside and might have its roots in warrior-like patriarchal traditional values (ibidem). Research of Chinese prostitution should thus probably begin with empirical research in China and be careful to recognize the cultural differences within China itself. 


\section{'True' Chinese transnational crime: immigrant crimes}

\section{Crimes of Chinese immigrants in continental EU}

\section{Background}

China has had a long and rich immigrant tradition. In 2010, the Chinese diaspora included over 40,3 million people, making it the third most numerous and second only to the German and the Irish diaspora (Poston Jr and Wong, 2010). Most 'overseas Chinese' live in South-East Asia. In developed countries, the American Chinese community with more than 4 million people ( $10 \%$ of global Chinese diaspora) is undoubtedly the largest, followed by Chinese living in the EU - more than 2 million people (5\% of the global diaspora) (Gui, 2011), roughly the entire population of Slovenia. The number of Chinese immigrants from the People's Republic of China (PRC) is much lower when considering only PRC-born immigrants (without their children): as of 2010, according to the UN estimates, there were 8,3 million PRC-born Chinese immigrants officially registered outside China, Hong Kong, Macau, and Taiwan in 2013, accounting for only $0,22 \%$ of the entire PRC population (Bofulin, 2014). The Chinese diaspora is growing at a rate of about 1,2\% per year (Poston Jr and Wong, 2010).

However, saying 'Chinese person' can be vague and misleading. It could perhaps be argued that Europeans do not belong to a culture, as unified as the Chinese one, and therefore the adjective 'European' encompasses more variety than the adjective 'Chinese'.

Out of the 1,4 billion people, less than 3\% of Chinese have ever been tempted to emigrate from China in the last century. Most Chinese immigrants come from only three coastal provinces: Guangdong, Fujian, and Zhejiang. And then, even within one province, only a few counties, towns and cities provide the bulk of immigrants, whereas people from other places within the same province are not interested in leaving China at all. There is a subculture of immigration and even significant pressure on young people by their parents, relatives, and peers to emigrate and try their luck 'overseas'.

In researching crimes by Chinese immigrants, it is therefore important to determine where in China the perpetrators and victims come from. 
Chinese immigration happened in three waves (Ding, 2010). The first wave started in the mid-19th century and ended around 1950. Chinese people from Guangdong (Cantonese people) and Fujian province moved to South-East Asia and to the US.

The second wave, which lasted from 1950 to 1980, included Chinese people from Hong Kong, Macau, and Taiwan who emigrated to the US, UK, Canada, Australia, New Zealand and Japan.

The third wave began after the Reform and Opening Up Policy in the People's Republic of China in 1978, gaining increasing momentum in the 1990s. Its main targets were the EU and its neighbouring states. These Chinese immigrants also established a strong presence in Africa and Latin America. The third wave has been dominated by immigrants from Zhejiang province, especially from the coastal city of Wenzhou and its rural surroundings. The correct term for these immigrants would be Wenzhounese.

In recent years, there has also been a significant rise of mostly female immigrants from Manchuria (the Heilongjiang, Jilin, and Liaoning provinces). These women are drawn to France, where they work in the service industry. Their number is already estimated to be around 15.000.

\section{Origins of Chinese migrants in the EU and their characteris- tics}

According to 2011 estimates (Latham and $\mathrm{Wu}, 2011$ ), the EU member states with the highest number of Chinese immigrants are: the United Kingdom - 630.000; France - 540.000; Italy - 330.000; Spain - 170.000; Germany -170.000 ; and the Netherlands -160.000 immigrants. The number of Chinese immigrants in the continental EU (excluding the UK) is estimated to be around 1,75 million. It should be noted that most of these immigrants were born in the PRC, meaning Chinese immigrants in the EU represent a formidable 20 to $25 \%$ of the all the 8,3 million individuals that came to the continent during the third wave. Most of them are of Wenzhounese origin. Among the Wenzhounese, the immigrants from Qingtian are especially significant.

The Wenzhou prefecture (Chin. Wenzhou shi) of Zhejiang province is located $450 \mathrm{~km}$ south of Shanghai. Outside Wenzhou City, a large and modern industrial port, the region is a fragmented coastal area with a 
mountainous rural hinterland, difficult to access even in times of modern transport. Agricultural yields are modest and the population has embraced the practice of running small family businesses since the early $19^{\text {th }}$ century. ${ }^{6}$ The tradition persisted underground even during the Cultural Revolution. Coastal towns and villages in the Wenzhou prefecture have long been notorious for smuggling and even for petty piracy during periods of social instability. All this is criminologically relevant, because the Wenzhounese people have historically developed an attitude which sees any state power as an obstacle to their business goals or simply as a predator.

The rural element infuses the local Wenzhounese culture with a great deal of deep-rooted traditions and superstitions. People rely on resilient social networks of clans, fraternities, and old friends. The strength of these networks seems to be much more formidable than even traditional Chinese social connections called guanxi. ${ }^{7}$ Distrust of any and all outsiders is typical of the Chinese psyche (Bo, 1991) and Wenzhounese people are suspicious of every other Chinese. Finally, the Wenzhounese speak a very difficult and untypical dialect of Chinese, incomprehensible even in neighbouring towns and villages. In short, Wenzhou prefecture is mutatis mutandis culturally somewhat similar to 'scofflaw' (lawless) areas' in Europe, such as South Italy and Albania.

Within a larger Wenzhounese immigrant community, we find a significant group from Qingtian County (Chin. Qing tian xian), located $50 \mathrm{~km}$ from Wenzhou City. The Qingtianese maintain a separate but very strong

6 The area has been known for its stone carving prowess since ancient times. During colonisation by foreign super-powers in the beginning of the 20th century, the stone merchants established contacts with the first foreigners and started to emigrate to sell small stone figurines, first to Japan and then to France. There was a vibrant community of Wenzhounese merchants in Paris as early as the 1920s (Bofulin, 2014).

7 Without going into too much nuances of the definition, guanxi (loosely translated as connections; the term with the same Chinese characters is also used in Japanese as kankei) are the Chinese cultural equivalent to Western notions of networking and social capital. They have some cultural specifics and yet it is doubtful to assume that such a modus operandi is uniquely Chinese, as argued by some Chinese scholars (see Wang, 2014). As the concept of guanxi is applied all over China, it alone cannot explain the economic successes of some areas. As Studwell (2010) points out, guanxi in China often do not work and can be highly unreliable, but guanxi networks are very efficient within the Chinese diaspora in South-East Asia. 
identity. As of 2010, the official statistics of Qingtian County give a population count of 336.500 people, 230.000 of which live abroad as immigrants (Bofulin, 2014). The remaining population is more or less concentrated in Qingtian Town which has grown from 20.000 to more than 100.000 people.

Far from being a typical backwater town in the Chinese countryside, Qingtian Town is incredibly prosperous and cosmopolitan, even earning the nickname of 'little Hong Kong'. Its immigrant community is of vital importance for the local economic development as official statistics for 2009 state an income of $\$ 2.137$ million (sic!) from migrant remittances alone (Bofulin, ibidem). If the estimate of 230.000 migrants is correct, that would mean that the average Qingtianese abroad remits more than $\$ 9.000$ annually. The Qingtianese group is generally present in Italy, Spain, and France. They also speak a specific dialect which is so different from Wenzhounese that the dialect speakers cannot understand each other. However, most Qingtianese people are also fluent in Wenzhounese, giving them the upper hand in collaborating with immigrant business circles from Wenzhou.

\section{Predicting typical crimes of Chinese immigrants}

To avoid prejudices and racist hysteria, it should be emphasised that Chinese migrants' crime rate all over the world is very low, especially for violent crimes. In most countries, including the US and Canada (Rumbaut $e t$ al., 2007) (but not Japan), the crime rate of Chinese immigrants is in fact lower than the crime rate of the domestic majority population.

Furthermore, crimes of Chinese immigrants - when they occur - are mostly harmful to the Chinese community itself and not to the local population. The Chinese are not only the perpetrators of these crimes, they also comprise the bulk of the victims. Researching, predicting, preventing and punishing crimes of Chinese immigrants would thus primarily benefit Chinese immigrants themselves. Typical crimes connected with Chinese immigrants are:

- 'Low skill' crimes, which do not require expertise: smuggling (e.g. meat) and avoiding customs taxes and duties; importing or manufacturing counterfeit goods (especially textile and leather); human smuggling 
and clandestine immigration, usually for the purpose of illegal and undocumented labour.

- 'High skill' white-collar crimes which require special expertise: tax evasion, tax fraud, business fraud, investment visa fraud ${ }^{8}$, establishing fake 'strawman' companies to smuggle workers into the EU, and exploitation of migrant labour.

Regretfully, the exploitation of Chinese migrant labour is pervasive in numerous industries where Chinese migrants are traditionally employed, either legally or illegally. Chinese owners of laundromats and restaurants consider this completely normal. It is especially common in the Italian textile industry (Calleri, 2016). Chinese workers are underpaid, work overtime without compensation, are excluded from social security, denied leave, etc. In worse cases, they must also live and sleep in the factory, are denied freedom to leave the premises and face dangerous, even lethal working conditions, thus becoming slaves in all but name. This problem deserves to be explored in more detail.

\section{Economic incentives for illegal labour exploitation: the Wenzhou model}

Wenzhou City has been repeatedly declared "the most enterprising city in China". It is the Chinese unofficial centre of shadow banking, land grabbing, and the monopolisation of light industries. E.g. $70 \%$ of plastic lighters in the world are made in Wenzhou (Ramzy, 2011). Its businessmen have repeatedly demonstrated vast experience with avoiding and corrupting law enforcement and bending the rules to their advantage. In China, they enjoy a reputation for dishonesty, trickery and an uncanny ability to haggle. ${ }^{9}$

8 In cases where investment in real estate is a prerequisite for getting an investor's visa, it is not uncommon to sell the same real estate numerous times to many consecutive Chinese investors. Visas, issued for planned business projects which are supposed to create a certain number of new jobs, lend themselves to fraud even more easily. As the newest case of massive visa fraud in the US reveals, the investors proposed construction projects which were never built. The US were defrauded in the excess of $\$ 50$ million in subsidies for construction projects (Bukhari, 2017).

9 Such a reputation might not be entirely deserved and could also be the result of envy as Wenzhounese people are allegedly the most common group among 
The Wenzhounese are well versed in aggressively creating efficient low-cost, labour-intensive businesses in unsophisticated, 'brute force' ways. Their most typical tactic involves clusters of small family businesses which are located in the same area where they mutually cooperate to the detriment of local competition (Bongardt and Neves, 2007). Where small and medium enterprises (SMEs) in the West are often hindered by inheritance procedures (the company must be divided among heirs or the oldest heir must pay the others their shares), this obstacle does not apply to a Wenzhou company. When the owner of the business passes away, the business is not divided among heirs into smaller units but instead continues to be managed collectively by surviving family members.

Nevertheless, in spite of all its obvious advantages, the so-called Wenzhou business model is self-defeating overseas. The greatest weakness of Wenzhounese businessmen lies in two aspects of their business culture: (a) cost-cutting mentality (paying workers very low wages and producing low quality goods) and (b) an utter lack of formal education (often attending only primary school). In China, it is often said that Wenzhounese people never attempt a business that the owner or the investor cannot understand; so their entrepreneurial complexity remains low. Investment into high tech gadgets, software, media, the internet and other goods and services with high added value is therefore discouraged. Due to the lack of education, the Wenzhounese are often also powerless to surmount language and cultural barriers when faced with an international context.

In times of economic growth, when a group of Wenzhounese accumulates enough capital to potentially upgrade their SME business to a large modern corporation, they are often simply incapable of coping with such sophistication. Their deep distrust of all outsiders also more or less excludes services from experts, such as lawyers, accountants, managers, consultants and even interpreters. The cost-cutting mentality also prevents them from hiring skilled workers. Complex business ventures with international elements are therefore hobbled from the start and remain quite rare. Large profits, often in cash, can be invested only into real estate or

China's nouveaux riches. They often buy the best real estate in large cities, (out-pricing the local population), while they lack and even intentionally ignore formal education which is the unquestionable pillar of Chinese traditional values, reinforcing existing prejudices and fears. 
into similar business ventures (restaurants, shops, and hotels), inevitably leading to saturation and stagnation.

In times of recession when demand is low, the Wenzhou model is bound to lead quickly to collapse because their source of income is based on producing huge amounts of cheap goods with a very low profit margin. If costs cannot be controlled anymore by cutting, the business fails to generate a profit and is forced to close down or at least downsize.

Overall, the very economic essence of the Wenzhou model lies in aggressive cost-cutting in various areas (labour, materials, taxes and other duties, administrative costs). Such a mentality inevitably produces strong incentives for various (cost-cutting) crimes: smuggling, tax evasion and tax fraud, and above all - labour exploitation and the violation of workers' rights.

\section{Estimating the costs of illegal Chinese immigration}

It is not difficult to logically deduce the reasons why illegal migration is preferred to the legal alternative. Illegal migration can be: (1) cheaper; (2) quicker; (3) more convenient and 'user friendly' (less bureaucracy and red tape), and (4) 'safer' - from the point of view of an illegal immigrant who lacks access to information and legal knowledge.

There can be very few arguments against the fact that in the increasingly bureaucratic modern world, illegal immigration is often quicker and more convenient. Furthermore, even if illegal immigrants are caught by the authorities, the same bureaucracy provides them with many options and opportunities (applying for asylum, government amnesties, etc.) to prolong their stay for many months, even years.

As for safety, the situation is objectively speaking quite the opposite, since many illegal immigrants fall victim to various kinds of abuse or even die on the way. It should, however, be emphasized that illegal immigrants have little to no knowledge about the country to which they intend to immigrate and do not speak the language of that country. Fear of everything foreign, which in the case of Chinese illegal immigrants often borders on paranoia, compels illegal immigrants to trust human smugglers and illegal employers of their community because they at least provide an illusion of protection against the hostile outside world. 
The only enigma remaining is the price of illegal immigration. Estimates range from 10.000 to 75.000 or even 100.000 US dollars for smuggling a single Chinese illegal immigrant into a developed Western country. This information does not seem credible in the case of Wenzhounese and Qingtianese immigrants. By using other available information, it is possible to make a more realistic estimate.

The Wenzhounese immigration to the EU is strictly for economic reasons, i.e. the opportunity to earn much higher wages than at home. We should therefore assume that the costs of immigration, legal or illegal, are a matter of rational economic calculation. If the immigrants immigrate for political (escaping state repression or religious persecution) or socio-economic reasons (relocating abroad indefinitely in search of a better life for themselves and their children), they often accept very high, even unbearable costs. However, the immigration costs for Wenzhounese should only be considered as an investment to be returned to the investor over a certain period of time.

According to Qingtian County official estimates, an average Qingtianese immigrant remits $\$ 9.000$ annually. Assuming that remittances from legal and illegal immigrants are of a similar amount, we can deduce that the yearly remittance should cover the immigration costs in a short time span, i.e. from one to three years. It is likewise well known that the most notorious Chinese human smuggler in the US, Chen Chui Ping alias Sister Ping, used a standard tariff of $\$ 18.000$ per smuggled person. The standard price was such common knowledge among Chinese Americans that wives of illegal immigrants were nicknamed wan ba sao, 'Ladies Eighteen Thousand' (Zhang, 2007). From this information, we can deduce that the price of smuggling a single Chinese immigrant should be roughly equal to an average of two-year remittance: somewhere between 15.000 and 20.000 dollars or euros. ${ }^{10}$

This price is highly competitive and can in fact be cheaper than the cheapest options available for legal immigration to the EU, i.e. establishing

10 This estimate is confirmed by the case of the Xiang (Hsiang) crime family which smuggled hundreds of illegal labourers into Prato and subsequently terrorised them with ever increasing extortion demands. The initial fee was 17.000 Euros, paid in three instalments. The criminal network of Xiang family was successfully broken by the Anti-mafia Investigative Division. See Calleri (2016). 
a limited liability company in East Europe. For Chinese immigrants interested in the Italian, Austrian, and German markets, we can make an appropriate comparison with immigration costs to Slovenia. Slovenia is located the inside Schengen area, providing hassle-free access to Italy and Central Europe.

Establishing a limited liability company requires $€ 7.500$ of initial capital and the ability to pay some notary and legal costs, immigration consultants, consular fees, as well as the cost of travelling to the Slovenian consulate in Peking or Shanghai. All together this puts the final price tag at roughly $€ 10.000$. However, in this case the residence permit must be prolonged every year. The priority immigration procedure, which guarantees an automatic three-year residence permit with only one extension necessary for 5 years requires an investment of $€ 30.000$ investment (including $€ 7.500$ of initial capital) and at least $€ 3.000$ for other expenses, putting the final price tag at a hefty $€ 33.000$. Because this is one of the cheapest options for the EU, it is unsurprising to see illegal Chinese immigration continue.

\section{City of Prato as an example of Chinese immigrant crimes on a massive scale}

Prato is a city in Tuscany, located close to Florence. At least 30.000 to 40.000 of its 191.000 inhabitants are estimated to be Chinese migrants (Latham and $\mathrm{Wu}, 2013$ ). As of 31 December 2013, only 16.182 Chinese residents are legally registered (Johansen et al., 2015). Prato has been the heart of the Italian textile industry for decades. The first Chinese migrants from Wenzhou began to arrive in the 1990s and started working in small, family-owned textile factories. Slowly, the Wenzhounese community in Prato expanded as their companies started to increasingly monopolise the so-called fast fashion segment (Italian: pronto moda).

Nowadays, the Chinese businesses, mostly owned by Wenzhounese and Qingtianese families, directly or indirectly control approximately one third of the entire garment and textile turnover worth around $€ 4,5$ billion annually and an additional 2,5 billion Euros in exports. Chinese businesses are 
therefore expected to earn an aggregate income of more than 2 billion Euros. The orders for textile and garment production were outsourced to Prato from textile giants (Zhang, 2015), producing affordable and fashionable clothing (e.g. Zara and many others).

To remain competitive, i.e. cheaper and quicker than Italian companies and even production facilities overseas (China, Vietnam, Bangladesh), some Chinese textile businessmen have developed and perfected, as numerous investigations by Italian law enforcement have revealed, increasingly illegal and criminal business tactics. For the local textile industry, however, Prato did not represent a threat, but rather an opportunity of "outsourcing to China without going to China" (Cipriani, 2016). Cheap Chinese fabrics were imported and often smuggled from China, while the final work was done by the meagrely paid Chinese workers themselves.

The city has the largest Chinatown in the entire EU. In proportion to its population roughly one fourth of the inhabitants are Chinese; since 2009, more than half of new-borns have been Chinese (Bressan and Krause, 2014). Prato has in the last decade attracted considerable attention from scholars in migration, multi-culturalism, ethnography, Chinese studies, business models and business networks, public spaces, etc. (see Ceccagno, 2003, 2012; Ottati, 2009, 2014; Santini et al., 2011; Chang, 2012; Nielsen et al., 2012; Barbu et al., 2013; Lan and Zhu, 2014; Lombardi and Sforzi, 2016; Lazzeretti and Capone, 2017). However, virtually all of these analyses remain in the 'politically correct area' and fail to mention that the district of Prato also suffers from inordinate levels of crime. According to a recent Transcrime analysis (Riccardi, 2017), Prato has comparable levels of organised crime infiltration to traditional 'mafia strongholds' in the South of Italy: Campania, Calabria, and Sicily.

The Antonino Caponnetto Anti-mafia foundation has identified three types of Chinese immigrant criminal associations in Prato and its surroundings (Calleri, 2016):

1. A mafia-type association, according to the definition given in Article 416 bis of the Italian Penal Code, mostly involved in human smuggling, extortion of prostitutes and to a lesser degree in illicit drug trafficking;

2. Gangs of young Chinese delinquents, mostly involved in robberies and violent crime;

3. So-called nuova mafia borghese, new bourgeois criminal groups of Chinese businessmen and entrepreneurs. 
Contrary to expectation, the crimes of Chinese mafia-type associations and Chinese gangs are completely dwarfed in comparison to bourgeois criminal groups as demonstrated below.

In 2009, the Italian authorities conducted their first major operation against Chinese criminal entrepreneurs. Operation Economia Sicura saw the Italian Financial Guard (Guardia di Finanza) seize 50.000 counterfeit bags and discover hundreds of meters of fabrics used to make Louis Vuitton and Gucci fashion accessories. When a team of labour inspectors raided a textile factory near Florence and discovered 70 illegal Chinese workers, living and working underground with their entire families, sharing same beds during their shifts, the team had to be assisted by the military (Calleri, 2016).

This operation was followed by the most successful investigation so far. Codenamed Money2Money and once again conducted by the Financial Guard, it was finalised in July 2010 and resulted in the arrest and indictment of 158 people, the confiscation of 181 pieces of real estate (many of them expensive villas) and 166 luxury cars, the majority being the Porsche brand, the freezing of 300 bank accounts, and the seizure of 73 companies. The value of seized assets was estimated to be around $€ 80$ million. Money transfers, made by the indicted individuals to China, was always done in small amounts (so-called smurfing), but they amounted together to more than $€ 2,7$ billion between 2006 and 2010 (Calleri, 2016).

It is quite probable that criminal Chinese entrepreneurs have been highly adept at avoiding Italian law enforcement. Therefore, a vast dark number of unreported crime continues to exist. But even if we ignore this assumption, simply comparing the amount of unrecorded income, wired to China ( $€ 700$ million), identified by various investigations, with the amount of the entire turnover of the Chinese textile businesses in Prato ( $€$ 2 billion) we get a disturbing picture of the deeply entrenched illegality. That means a third of the Chinese textile corporate income in Prato was illegally diverted.

Obviously, this is tax fraud on a massive scale, but tax crimes might be just the tip of the iceberg, since the main question is just how such high earnings were achieved in the first place? Even in times of the global financial crisis when Italian businesses were struggling with the high costs of labour and materials, Chinese businesses managed to be immensely profitable. It is therefore possible to suspect other (economic) crimes to 
raise profits: the illegal exploitation of Chinese workers, paying them much below the Italian minimum wage, avoiding social security contributions, buying materials on the black market or smuggling them from China.

Of course, it is almost impossible to give a final estimate of the proportion of Chinese businesses in Prato which routinely and systematically engage in illegal practices. Some commentaries (e.g. Cipriani, 2016) even state that only a minority of Chinese businesses work in compliance with Italian laws and regulations, as law compliance would make them uncompetitive. In Prato, it is well known that most Chinese-owned companies are established for a very short time span (Ceccagno, 2012). If the company closes because of shrinking profits, this is referred to as 'natural death'. The opposite, 'unnatural death', happens if the company gets in trouble with the authorities and must pay hefty fines and taxes. Such a company files for bankruptcy and a new company emerges on the same address or nearby, like mushrooms from an underground mycelium (the Chinese poetically refer to it as 'phoenix from the ashes'). There is also a widespread tactic of 'name lending', i.e. elderly Chinese or immigrants who intend to return to China simply lend their name as de iure owners of companies. When trouble arises, the name lender is nowhere to be found and the de facto owner simply 'resets' the business with another name lender.

\section{Some intermediate conclusions about Chinese crime in Prato}

The Chinatown in Prato and its garment and textile businesses have been and will continue to be an interesting and highly complex phenomenon with no simple, 'quick fix' solutions in sight. Its model of integration for Chinese immigrants has been highly praised by numerous observers as well as denounced as an abject failure where a few unscrupulous immigrant businessmen ruthlessly exploit their own countrymen and pay no taxes nor social contributions to the Italian state. The victims of such a system have mostly been the Chinese immigrants themselves, while many Italian locals - often assuming the role of the 'victims' in the local right-wing populist media - have substantially profited from the Chinese: as landlords, outsourcing companies, notaries, and attorneys. The situation is further complicated by the observation that many of the Chinese exploited illegal 
workers do not see themselves as victims ${ }^{11}$ but only as pursuers of the ' $\mathrm{Eu}$ ropean dream' (higher income) stuck in temporary hardship. Prato used to have the highest percentage of business owners among its Chinese population, because literate people sometimes succeeded in working their way up to owning a small company. This implies that hope of a better life were not as far-fetched in the near past as they might seem today. What is more, the ideology of cultural relativism (e.g. "it is in the Chinese nature to work hard and patiently suffer") has spread from scholars to the Chinese community itself. Once adopted it has been quite skilfully applied by its leaders who claim that Chinese migrants are victims of systematic discrimination, such that even Italian citizens of Chinese descent are treated as second class. They state that Chinese businesses should more or less be left alone in their self-imposed isolation from the dominant Italian population. These claims often carry a lot of truth and therefore cannot simply be dismissed as entirely unfounded. However, the culture and tradition of a certain group of immigrants, however ancient and rich it may be, does not guarantee any immunity from local laws and regulations. Finally, in spite of rampant illegality in Prato's Chinatown, a significant number of Chinese businesses have nevertheless managed to respect laws, pay taxes, and remain competitive. Such positive examples should lead the way in combating unethical and criminal business practices.

\section{Conclusion: phantoms of Chinese transnational crime, real crime and new areas of research}

The distinction between real and mostly exaggerated transnational crime is not purely academic but has negative practical implications as well. Chasing criminal phantoms such as the Chinese Triads and fighting against overestimated social ills, such as sex trafficking, has logical consequences:

11 A factory of workers who were toiling 12 to 14 hours a day had no locks on the doors, meaning that the workers were free to leave at any time and therefore their exploitation cannot be regarded as forced labour. Indeed, nobody left. See documentary "Sirene: Indagine mafia cinese della Guardia di Finanza a Prato", available on YouTube website:

https://www.youtube.com/watch?v=8rZraoVPWkk. 
true problems, often persisting in plain sight, are neglected. Typical example would involve the police "liberate" voluntary prostitutes, all the while the exploitation of underpaid illegal labour in Chinese-owned restaurants and textile factories continues unhindered.

It is therefore unsurprising that the case of Prato as the largest 'Criminal enterprise' perpetrated by Chinese immigrants in the entire $\mathrm{EU}$, is much rarely covered by international media and even by scholars focusing on Chinese organised crime. Since Chinese immigrants tend to continue their isolation from mainstream society sometimes even into the $3^{\text {rd }}$ generation, empirical criminological research and field work, conducted together with language and culture specialists are much needed.

However, it should be emphasised that transnational crime of Chinese origin also occurs in areas with no connection to Chinese immigrants. So far, we can mention three important examples.

The first one, which is gaining considerable media attention, is cybercrimes perpetrated by Chinese hackers. These often seem to be state-sponsored, but as freelancer attacks are becoming increasingly 'popular' as well. ${ }^{12}$

The second example is the manufacture of synthetic opiates, new psychoactive substances (NPS), and precursor chemicals by Chinese chemists (see US Department of the Treasury, 2014; United Nations Office on Drugs and Crime, 2016; Riggs, 2017). Even though hard evidence is very difficult to obtain, numerous incidents point out that quite a few people and companies inside Chinese chemical and pharmaceutical industry are skilfully exploiting loopholes in the global prohibition regime without facing any serious response from the Chinese government. These problems deserve to be investigated in more depth and detail by scholars of organised crime.

Both of the aforementioned categories of crimes cannot be characterised as 'culturally specific' as their modus operandi is more or less unrelated to the perpetrators' cultural environment. It therefore makes no significant difference whether NPS are manufactured by the Chinese or by any other nationality. A Chinese cultural background is moreover mostly

12 The most recent worldwide attack was perpetrated using the WannaCry ransom ware crypto worm. Linguistic analysis of the ransom ware message sug96

gests Chinese speaking authors (Condra et al., 2017). 
irrelevant when investigating hacking attacks, since they could also be perpetrated by people from many other countries or even by international groups of cyber-criminals.

The last and very recent example of Chinese transnational crime are fraudulent call centres, mostly operated by Taiwanese nationals. So far it is unclear whether these call centres could also be considered 'culturally specific' (like the Nigerian "419" fraud, see Glickman, 2005) or whether the perpetrators simply copied successful fraud tactics and scripts from other countries. Surprisingly, even in criminally rather uneventful Slovenia, such a call centre was discovered and a vast criminal investigation, involving 150 policemen, followed (Pečarič, 2018). As the majority of the callers is stating that they were forced to call potential fraud victims, only six ring leaders have been arrested and are currently under investigation. Other callers are being assisted by the Slovenian Ministry of Interior as alleged victims of human trafficking. Interestingly, the representatives of the People's Republic of China insist that this is a completely false claim and that the callers are only trying to abuse loopholes in the unclear human trafficking legislation.

Many of the discussed cases clearly illustrate the contradictions between Western and Chinese cultural understanding of victims and victimizers. If Chin's empirical research (2014) is correct, Chinese prostitutes in the EU are not victims, however they are treated as such. If they also temporarily work as pimps or cashiers, they can suddenly turn into victimizers. Quasi-slaves, working in Prato underground textile factories, are without doubt victims, but as, to paraphrase Buddhist thought, "prisoners of their own mind" they do not see themselves as being condemned to years or even decades of misery and debt slavery. Workers in fraudulent call centres simply declared themselves victims and were believed.

These complex cases are challenging established paradigms and narratives of human trafficking (including sex trafficking). Obviously, there is a great need for empirical and more objective research of immigrant criminality with less reliance on generalised assumptions. 


\section{References}

"A Napoli record di omicidi", Gazzetta del Mezzogiorno, 28 January 2005. Available at:

http://www.lagazzettadelmezzogiorno.it/news/notizie-nascoste/28296/a-napoli-record-di-omicidi.html.

Alvarez, M.B. and E.J. Alessi, Human trafficking is more than sex trafficking and prostitution: Implications for social work. Affilia 2012, 27, no. 2: $142-152$.

Arsovska, J., Decoding Albanian organized crime: Culture, politics, and globalization. Oakland, Ca.: University of California Press, 2015.

Baker, C.N., An examination of some central debates on sex trafficking in research and public policy in the United States." Journal of Human Trafficking, 2015, 1, no. 3: 191-208.

Barbu, M., M. Dunford, and L. Weidong, Employment, entrepreneurship, and citizenship in a globalised economy: the Chinese in Prato." Environment and Planning A, 2013, 45, no. 10: 2420-2441.

Behan, T., The Camorra: Political Criminality in Italy. Routledge, 2005.

Beneduce, T., Napoli, nel 2016 omicidi in aumento «Le stese sono il nostro terrorismo». Corriere della Sera, 28 January 2017. Available at: $\mathrm{http}: / /$ corrieredelmezzogiorno.corriere.it/napoli/cronaca/.

Bo, Y., The ugly Chinaman and the crisis of Chinese culture. Allen \& Unwin, Sydney, 1992.

Bofulin, M. (2014), Sodobni migracijski procesi v Ljudski republiki Kitajski / People's Republic of China's Contemporary Migration Processes. Ćasopis za kritiko znanosti, 2014, 258, 125-136.

Bongardt, A., and M. Santos Neves, The role of overseas Chinese in Europe in making China global: The case of Portugal. No. 44. Departamento de Economia, Gestão e Engenharia Industrial, Universidade de Aveiro, 2007.

Bressan, M., and E.L. Krause, Ho un luogo dove lavoro e un luogo dove abito. Diversità e separazione in un distretto industriale in transizione. Mondi migranti, 2014.

Broadhurst, R., K.W. Lee, and C.Y. Chan, Crime trends. Understanding criminal justice in Hong Kong: 45-68, 2008.

Bukhari, J., Feds Raid a Suspected Green Card Fraud Ring for Wealthy Chinese Investors", Fortune, 6 April 2017. Available at: 
http://fortune.com/2017/04/06/green-card-fraud-chinese-investors/.

Calleri, S., Criminalità Cinese a Prato, Firenze e dintorni rapporto 2016, Fondazione Antonino Caponnetto, 2016. Available at:

https://stopmafia.blogspot.ru/2016/07/criminalita-cinese-report2016.html.

Ceccagno, A., New Chinese migrants in Italy. International Migration, 2003, 41, no. 3, 187-213.

Ceccagno, A., The hidden crisis: the Prato industrial district and the once thriving Chinese garment industry. Revue européenne des migrations internationales, 2012, 28, no. 4, 43-65.

Chang, A., 20th century Chinese migration to Italy: The Chinese diaspora presence within European international migration. History Compass, 2012, 10, no. 2: 179-190.

Chappell, B., European Union Report Details Growth Of Human Trafficking. NPR, 15 April, 2013. Available at:

http://www.npr.org/sections/thetwo-way/2013/04/15/177326963/european-union-report-details-growth-of-human-trafficking.

Chin, K.L. Going Down to the Sea: Chinese Sex Workers Abroad. Silkworm Books, 2014.

Choi-Fitzpatrick, A., The good, the bad, the ugly: Human rights violators in comparative perspective." Journal of Human Trafficking, 2016, 2, no. 1: 1-14.

Chu, Y.K., The Triads as business. Routledge, 2002.

Cipriani, S., This is China, not Italy. The Huffington Post. 2016. Available at:www.huffingtonpost.com/simone-cipriani/.

Condra, J., et al., Attribution of the WannaCry ransomware to Chinese speakers. 2017. Available at:

https://www.flashpoint-intel.com/blog/linguistic-analysis-wannacryransomware/.

Ding, S., Sons of the Yellow Emperor go online: The state of the Chinese digital diaspora. Global Migration and Transnational Politics, Working Paper No. 13, July 2010. Available at:

http://gmtp.gmu.edu/publications/gmtpwp/gmtp_wp_13.pdf.

Ebenstein, A., and E.J. Sharygin, Demographic change, prostitution, and sexually transmitted infection rates in China. In The Oxford Handbook of the Economics of Prostitution, 2012. 
Finckenauer, J.O., and K. Chin., Sex trafficking: a target for situational crime prevention? In Situational Prevention of Organised Crimes, pp. 58-80, Karen Bullock, Ronald V. Clarke, and Nick Tilley, eds., 2010.

Glickman, H., The Nigerian "419" advance fee scams: prank or peril? $\mathrm{Ca}$ nadian Journal of African Studies/La Revue Canadienne Des Études Africaines, 2005, 39.3, 460-489.

Gozdziak E. and M.N. Bump, Data and Research on Human Trafficking: Bibliography of Research-Based Literature, A Final Report to NIJ Grant 2007-VT-BX-K002. Washington, DC: Institute for the Study of International Migration, Georgetown University, 2008.

Gui, S., "The Contribution of Overseas Chinese to China's Developement", in Qu, Zhang Lou and Li (eds), Annual Report on Overseas Chinese Studies, Beijing: Social Sciences Academic Press, 2011.

Hong Kong Monthly Digest of Statistics, Crime Statistics in 2015, Census and Statistics Department, The Government of the Hong Kong Special Administrative Region, Hong Kong, 2016.

Hoyle, C., M. Bosworth and M. Dempsey, Labelling the victims of sex trafficking: Exploring the borderland between rhetoric and reality." Social \& Legal Studies, 2011, 20, no. 3, 313-329.

Johanson, G., N. McAuliffe and M. Bressan, Chinese migration to Europe: Prato, Italy, and beyond. Springer, 2015.

Lan, T., and S. Zhu, Chinese apparel value chains in Europe: low-end fast fashion, regionalization, and transnational entrepreneurship in Prato, Italy. Eurasian Geography and Economics, 2014, 55, no. 2, 156-174.

Latham, K., and B. Wu, Chinese immigration into the EU: New trends, dynamics and implications. London: Europe China Research and Advice Network, 2013.

Lazzeretti, L., and F. Capone, The transformation of the Prato industrial district: an organisational ecology analysis of the co-evolution of Italian and Chinese firms. The Annals of Regional Science, 2017, 58, no. 1, 135-158.

Lee, K.-W., R.G. Broadhurst, and P.S.L. Beh., Triad-related homicides in Hong Kong." Forensic science international, 2006, 162, no. 1-3, 183190.

Lombardi, S., and F. Sforzi. "Chinese manufacturing entrepreneurship capital: evidence from Italian industrial districts." European Planning Studies, 2016, 24, no. 6, 1118-1132. 
Murray, D.H., and B. Qin, The origins of the Tiandihui: the Chinese triads in legend and history. Stanford University Press, 1994.

Nielsen, I., O. Paritski, and R. Smyth, A minority-status perspective on intergroup relations: A study of an ethnic Chinese population in a small Italian town. Urban Studies, 2012, 49, no. 2, 307-318.

Ottati, G.D., An industrial district facing the challenges of globalization: Prato today. European Planning Studies, 2009, 17, no. 12, 1817-1835.

Ottati, G. D., A transnational fast fashion industrial district: an analysis of the Chinese businesses in Prato. Cambridge Journal of Economics, 2014, 38, no. 5: 1247-1274.

Pečarič, J., Obsežne kriminalistične preiskave trgovine z ljudmi”, Delo, January 18, 2018. Available at:

www.delo.si/novice/kronika/neuradno-obsezne-kriminalisticnepreiskave-financnih-goljufij.html.

Petta, D.L., As tríades e as sociedades secretas na China: entre o mito e a desmistifição. Revista Brasileira De Ciencias Sociais, 2017, vol.32, n.93. Available at:

www.scielo.br/pdf/rbcsoc/v32n93/0102-6909-rbcsoc-3293092017.pdf.

Poston Jr, D.L., and J.H. Wong, The Chinese diaspora: The current distribution of the overseas Chinese population. Chinese Journal of Sociology, 2016, 2, no. 3, 348-373.

Ramzy, A. "When Wenzhou Sneezes", Time, November 28, 2011. Available at: http://content.time.com/time/magazine/article/.

Riccardi, M. et al., Assessing the risk of money laundering in Europe. Final report of project IARM. Milano: Transcrime, 2017.

Rumbaut, R.G., et al., Debunking the myth of immigrant criminality: imprisonment among first- and second-generation young men. Migration Information Source, 1 June 2006. Available at: https://www.migrationpolicy.org/article/.

Santini, C., S. Rabino, and L. Zanni, Chinese immigrants socio-economic enclave in an Italian industrial district: the case of Prato. World Review of Entrepreneurship, Management and Sustainable Development, 2011, 7, no. 1, 30-51.

Saviano, R., Gomorra: viaggio nell'impero economico della camorra. Milano: Mondadori, 2006.

Sergi, A., Mafia and politics as concurrent governance actors. In P.C. van Duyne, A. Maljevic, G.A. Antonopoulos, J. Harvey, and K. von Lampe, 
(eds.) The relativity of wrongdoing. (pp.43-70) Oisterwijk: Wolf Legal Publishers, 2015.

Silverstone, D., From Triads to snakeheads: organised crime and illegal migration within Britain's Chinese community". Global Crime, 2011, 12, no. 2, 93-111.

Spencer, J.R., International Law, People Trafficking and the Power to Stay Criminal Proceedings for Abuse of Process. The Cambridge Law Journal, 2014, 73, no. 1, 11.

Studwell, J., Asian godfathers: money and power in Hong Kong and South East Asia. Profile Books, 2010.

Sui, C., Film exposes London's sex industry underworld", BBC News, 23 June, 2017. Available at: http://www.bbc.com/news/world-asia40363513.

Varese, F. and R.WY Wong, Resurgent Triads? Democratic mobilization and organized crime in Hong Kong. Australian \& New Zealand Journal of Criminology, 2017, DOI: 0004865817698191.

Wang, P., Extra-legal protection in China: How guanxi distorts China's legal system and facilitates the rise of unlawful protectors. British Journal of Criminology, 2014, 54, no. 5, 809-830.

Weitzer, R. New directions in research on prostitution. Crime, Law and Social Change, 2005, 43, no. 4, 211-235.

Weitzer, R., The social construction of sex trafficking: Ideology and institutionalization of a moral crusade. Politics \& Society, 2007, 35, no. 3, 447-475.

Zhang, G., 'Made in Italy' by Chinese in Prato: the "carrot and stick" policy and Chinese migrants in Italy, The Online Journal of the China Policy Institute, November, 2010. Available at: https://cpianalysis.org/2015/10/22/.

Zhang, S.X., Smuggling and trafficking in human beings: all roads lead to America. Greenwood Publishing Group, 2007.

Zhang, S.X., Beyond the 'Natasha'story-a review and critique of current research on sex trafficking. Global Crime, 2009, 10, no. 3, 178-195.

Zheng, T., Ethnographies of prostitution in contemporary China: Gender relations, HIV/AIDS, and nationalism. Springer, 2009. 